\title{
Incidence of Hip Fractures of A-Bomb Servivors in Nagasaki City
}

\author{
Sadamichi Ikeda \\ The School of Allied Medical Sciences, Nagasaki University \\ Katuro Iwasaki, Toru Hirano and Kenji Yamada \\ Department of Orthopedic Surgery, Nagasaki University \\ Hisayoshi Kondo
}

Scientific Data Center for the A-Bomb Disaster, Nagasaki University School of Medicine

The incidence of hip fractures in Nagasaki Prefecture was higher than in Niigata ${ }^{7)}$, Tottor ${ }^{32}$, Okinawa Prefecture ${ }^{8)}$ where it was investigated at prefecture level. Therefore, it became necessary to determine whether such an increase in incidence was related to exposure to A-Bomb or not. More than 40 years have passed since A-Bomb disaster and victims are now the most part aged above 60 years. We investigated the incidence of hip fractures in such elderly victims to determine whether it was ascribable to exposure to A-Bomb or not.

\section{Materials and Method}

According to the national cencus in 1989, the population of Nagasaki Prefecture was 1, 574, 421. Further, the population of Nagasaki city was 445, 943 and 79, 700 (about 17. 9\%) of them were aged 60 years or older. In 1989 and 1990 there were 36, 763 and 36, 752 victims aged 60 years or older, respectively and they accounted for about half (46.1\%). The questionaire on hip fracture was sent to medical institutions with beds other than opthalmologic, otorhinolaryngologic, pediatric, and dermatologic clinics in Nagasaki City where $70 \%$ of victims lived. Hip fractures treated 1989 and 1990 were totalized and those aged 60 years or older were investigated for the presence and site of exposure of A-Bomb and compared by Mantel-Haenszel's survival rate-analyzing method.

\section{Results}

In 1989 there were 935 hip fractures aged 60 years in Nagasaki Prefecture. Of them, 238 were in Nagasaki City and 103 (43.3\%) of them had been exposed to A-Bomb. In 1990 there were 932 such fractures in Nagasaki Pre. of them, 235 were in Nagasaki City and 113 (48.1\%) of them had been exposed to A-Bomb. (Table 1)

The average age at a fracture was 81.3 years in the exposure group and 78.7 years in the non-exposure group in 1989. It was 80 years in the exposure group and 78.7 years in the non-exposure group in 1990. Briefly, the average age was slightly older in the exposure group.

The incidence of the hip fracture in females was compared between the exposure and nonexposure groups. As a result, it was no difference below 80 year. However, it was higher in the non-exposure group above 90 years. The same results were obtained in 1990. (Fig. 1) 
40 and 54 patients from the exposure group were clasified in the cervical and trochanteric fracture types, respectively and the cervical to trochanteric fracture ratio (abbreviated to type ratio) was 1.4 in 1989.

52 and 57 exposed group ware clasified in the cervical and trochanteric fracture types, respectively and the type ratio was 1.1 in 1990 .

56 and 82 patients from the non-exposed group were clasified in the cervical and trochanteric fracture types, respectively and the type ratio was 1.3 in 1989.

46 and 70 unexposed patients were clasified in the cervical and trochanteric fracture types, respectively and the type ratio was 1.5 in 1990.

The type ratio was compared in each city in females. The frequency of the cervical fracture was found to be higher in Uppsala ${ }^{9}$, but that of the trochanteric fracture was much higher in other cities. The frequency of the cervical fracture was higher in Nagasaki Prefecture than in Niigata and Tottori Prefecture and the type ratio in Nagasaki Prefecture ${ }^{1,3)}$ was almost the same as in Rochester City $^{2)}$. The type ratio in unexposed Nagasaki citizens was 1.3 which was almost the same as in Nagasaki Prefecture, but that in exposed group was 1.1 in 1990. (Table 2) The frequency of the cervical fracture is considered to be increased in the future.

For the purpose of determining whether was a difference in the incidence of hip fractures between

Table 1. The numbers of the hip fracture aged 60 years or older

\begin{tabular}{lll} 
& \multicolumn{1}{c}{1989} & \multicolumn{1}{c}{1990} \\
\hline Nagasaki Pre. & 935 cases & 932 cases \\
Nagasaki City & 238 & 235 \\
\hline Exposure to A-Bomd & 103 & 113 \\
Non-Exposure & 135 & 122
\end{tabular}

Table 2. Ratio of trochanteric to cervical fractures in females in various cities

\begin{tabular}{ccc}
\hline Uppsala & & 0.76 \\
Rochester & & 1.35 \\
Niigata Pre. & & 2.19 \\
Tottori Pre. & & 1.64 \\
Nagasaki Pre. & & 1.32 \\
\hline Nagasaki City & 1989 & 1990 \\
A-Bomb 1.35 & 1.09 & \\
Non A-Bomb & 1.28 & 1.52 \\
\hline
\end{tabular}

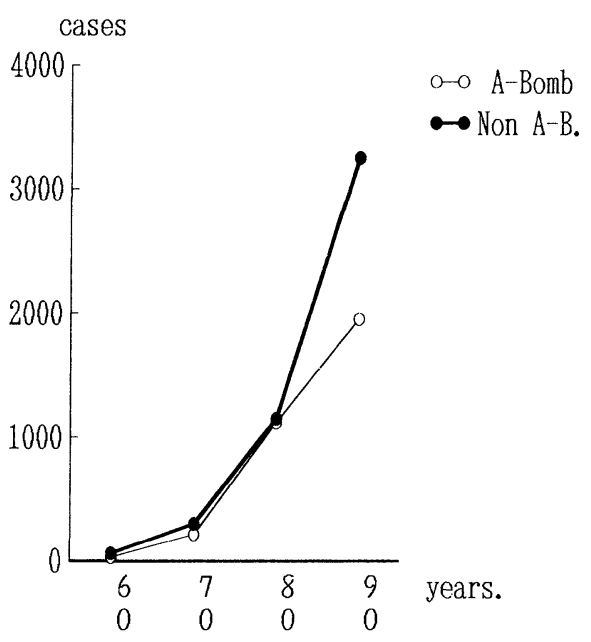

Fig. 1 Annual age specific incidence of hip fractures per 100,000 population in Nagasaki City in 1989 It was no difference below 80 years. However, it was higher in the non-exposure group above 90 years. The same results were obtained in 1990. 
the exposure and non-exposure groups, the significance of differences was assessed by Mantel Haenszel's survival rate-analyzing method in consideration of age group-related factors. As a result, the fracture expectation rates induced by Mantel Haenszel's method in the exposure group were 0.95(in the year 1989) and 1.06 (1990) as compared with 1 in the non-exposure group and to significant group-related difference was noted.

No significant group-related diffence was noted either when such analysis was performed in patients who were exposed to A-Bomb near ( $2 \mathrm{~km}$ or less) the center of explosion and at mome distant places (more than $2 \mathrm{~km}$ ) and those who entered Nagasaki City after the explosion of A-Bomb (control group). (Table 3) It is considered from these results that there is no relationship between exposure to A-Bomb and the incidence of the hip fracture.

\section{Discussion}

The incidence of the hip fracture aged 35 years or older was compared among various cities after correction with the composion ratio of Japan's population in 1986. It was found to be higher in Nagasaki Prefecture than in Niigata, Tottori, and Okinawa Prefecture. Further, it was found to be the same as in Hongkong ${ }^{1)}$ in males and Israel ${ }^{5)}$ in females (Fig.2).

Table 3 Results of Mantel-Haenszel's survival rate-analysing method

\begin{tabular}{lcc}
\hline & 1989 & 1990 \\
\hline Non A-Bomb & 1 & 1 \\
A-Bomb & 0.95 & 1.06 \\
\hline Control & 1 & 1 \\
2Km or less & 0.75 & 0.82 \\
more than 2Km & 1.26 & 1.09 \\
$\quad$ (not significant) & &
\end{tabular}

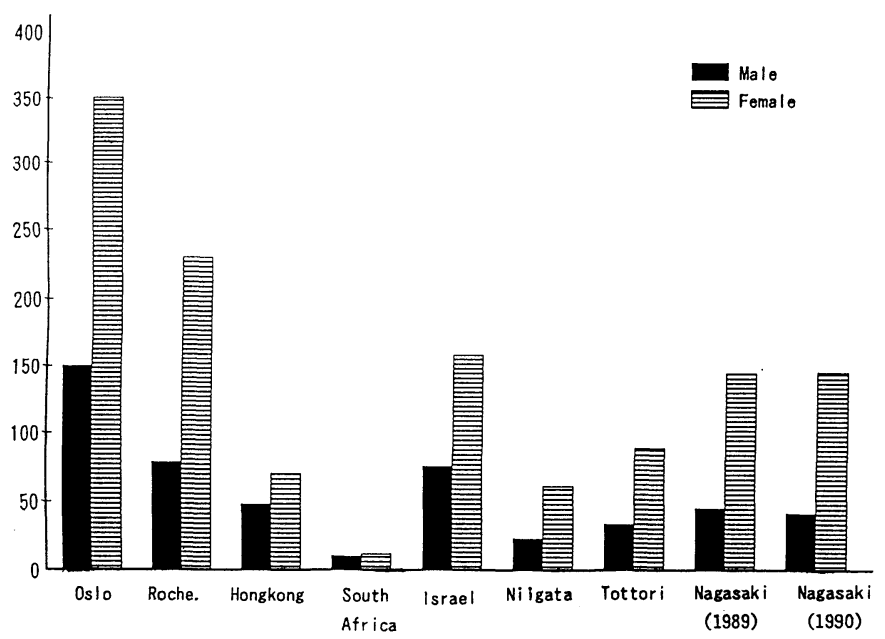

Fig. 2 Age-ajusted annual incidence of hip fractures per 100, 000 population from various studies Standardized to the Japan population in 1986

It was found to be the same as in Hongkong in males and Israel in females. In Nagasaki City its incidence was also increased similarly. 
In Nagasaki City the incidence of the hip frature in males was 44.3 (1989) and 49.9 (1990) and those in females, 146.1 (1989) and 146.3 (1990) per 100, 000 of population. Its incidence by age group was also increased similarly.

It was necessary to determine whether such an increase in incidence was related to exposure to A-Bomb or not.

In 1989 and 1990 the numbers of exposed fracture patients aged 60 years or older per 100,000 of population were 280.1 and 307.4, and those unexposed fracture patiensts, 316.0 and 285.6. Briefly, no significant difference was noted. Further, no difference was noted either when the significance of difference was assessed in consideration of age-related factors.

Aging was found to be slightly promoted by exposure to A-Bomb near the center of explosion when it was compared based on the condition of skin, appearance of gray hair, hearing capacity, and arterial elasticity.

However, it is generaly considered that there is no evidence for promotion of nonspecific aging by diseases other than cancer and leukemia ${ }^{6}$.

In the present investigation the averageage when hip fractures occurred was older in the exposure group than in the non-exposure group.

There are many reports that the pathologic fracture and necrosis and atrophy of bones were as radiologically-induced bone changes after radiation therapy ${ }^{4}$. However, there in no reports that the hip fracture as a late complication of A-Bomb-induced disease was studied in a large number of subjects. It considered from the results of the present investigation that there is no relationship between exposure to A-Bomb and the hip fracture.

\section{Summary}

The incidence of the hip fracture was investigated more than 40 years after exposure to A-Bomb when victims were for the most part aged above 60 years. The numbers of hip fractures in Nagasaki City were 238 in 1989 and 235 in 1990 and 102 and 113 (about 46\%) of them had beed exposed to A-Bomb. The incidence of such fractures per 100,000 in 1989 and 1990 were 280.1 and 307.4, respectively in the exposure group and 316 and 285.6 in the non-exposure group.

There was no significant difference between the exposure and non-exposure groups.

When the significant of difference was assessed by the survival-rate analysing method, no significant difference was noted between persons exposed and unexposed to A-Bomb and between victims exposed near the center of explosion and at more distant places. Taken altogether, exposure to A-Bomb is considered to produce no influence on the incidence of the hip frature.

\section{Refernces}

1) Chalmers J. et al. : Geopraphical variation in senile osteoporosis. J Bone and Joint Surg, 52 ; 667-675, 1970.

2) Gallagher J. C. et al. : Epidemiology of fractures of proximal femur in Rochester, Minnesota, Clin. Orthop. $150 ; 163-171,1980$.

3) Hagino H. et al. : Epidemiologic feature of changes in bone with aging. The Bone. 13 ; 31-38, 1989.

4) Hamada K. et al. : The early change in bone mineral metabolism due to radiation-measurement of bone mineral density in lumbar vertebra by quantitative computed tomography, Nippon Sanka Fujika Gakkai Zasshi. 43 ; 1-7. 1991.

5) Lewin S. et al. : Incidence of fractures of the proximal end of the femur in Jerusalem, J Bone and Joint Surg, 
$52 ; 1193-1202.1970$.

6) Shono N. et al. : Nuclear Radioactivity and A-Bomb induced Diseases. Japan Broadcasting Publishing Association, Tokyo, 1975.

7) Tahahashi H. et al. : Epidemiology of fractures of proximal femur in Niigata, Japan, Recent Progress Osteoporsis Research. 13 ; 73-76, 1987.

8) Uesato S. et al. : Incidence of the hip fracture and Influencing Factors on its in Okinawa Prefecture, Nihon Kotutaisha Gakkai, (Japan Society of Bone Metabolism Research). 7 ; 87.1989 (Japanese)

9) Zain E. B. S. et al. : Rising incidence of hip fracture in Uppsala, 1965-1980, Acta Ortho Scand. 55 ; 284-289, 1984.

\title{
大腿骨頸部骨折と原爆被爆の関係について
}

\author{
長崎大学医療技術短期大学部 \\ 池田 定 倫 \\ 長崎大学医学部整形外科 \\ 岩 崎 勝 郎 - 平 野徹 \\ 山田健 治 \\ 長崎大学・原爆被災学術資料センター \\ 近藤 久 義
}

長崎県の大腿骨頸部骨折発生率が新潟，鳥取，沖縄 県での調査結果より高くなった要因を検討する為に， 原爆被爆者のほほ 70 \%が居住する長崎市を対象とし て, 被爆が大腿骨頸部骨折発生頻度に影響があったか どうかについて 1989 年と 1990 年の 2 年間にわたり調 查した。

長崎市では, 1989 年に 238 例, 1990 年には 235 例の 発生があり，その中で被爆者は，それぞれ 102 例と 113
例であった。人口 10 万人当りでは，被爆者が 280.1 と 307.4 で，非被爆者は 316 と 285.6 で有意差はなかっ た。年齢階層別要素を組み入れた Mantel-Haenszen の生存率解析法でも, 被爆者と非被爆者間, そして近 距離被爆者と遠距離被爆者間においても発生率に有意 差がなかった。

以上の結果により, 被爆が大腿骨頸部骨折発生率に 及涩す影響はないと考えられた。 